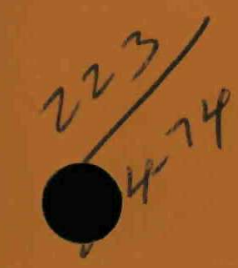

UCRL-51476

\title{
PREPARATION OF FISSION FOILS FOR FISSION IONIZATION CHAMBERS USING A PAINTING TECHNIQUE
}

\author{
James W. Behrens
}

November 14,1973

Prepared for U.S. Atomic Energy Commission under contract No. W-7405-Eng-48
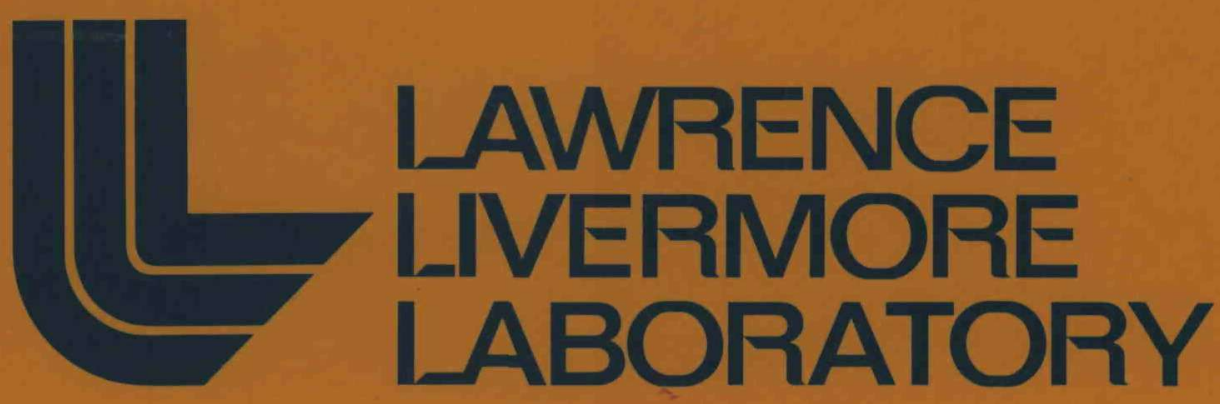

University of California/Livermore 


\section{NOTICF}

"This report was prepared as an account of work sponsored by the United States Government. Neither the United States nor the United States Atomic Energy Commission, nor any of their employees, nor any of their contractors, subcontractors, or their employees, makes any warranty, express or implied, or assumes any legal liability or responsibility for the accuracy, completeness or usefulness of any information, apparatus, product or proces disclosed, or represents that its use would not infringe privatelyowned rights."

Printed in the United States of America Available from

National Technical Information Service

U.S. Department of Commerce 5285 Port Royal Road Springfield, Virginia 22151

Price: Printed Copy \$_* ; Microfiche $\$ 0.95$

$$
\begin{gathered}
\text { *Pages } \\
\frac{1-50}{51-150} \\
151-325 \\
326-500 \\
501-1000
\end{gathered}
$$

NTIS

Selling Price

$\$ 4.00$

$\$ 5.45$

$\$ 7.60$

$\$ 10.60$

$\$ 13.60$ 


\section{DISCLAIMER}

This report was prepared as an account of work sponsored by an agency of the United States Government. Neither the United States Government nor any agency Thereof, nor any of their employees, makes any warranty, express or implied, or assumes any legal liability or responsibility for the accuracy, completeness, or usefulness of any information, apparatus, product, or process disclosed, or represents that its use would not infringe privately owned rights. Reference herein to any specific commercial product, process, or service by trade name, trademark, manufacturer, or otherwise does not necessarily constitute or imply its endorsement, recommendation, or favoring by the United States Government or any agency thereof. The views and opinions of authors expressed herein do not necessarily state or reflect those of the United States Government or any agency thereof. 


\section{DISCLAIMER}

Portions of this document may be illegible in electronic image products. Images are produced from the best available original document. 
TID $-4500, \mathrm{UC}-25$

Materials

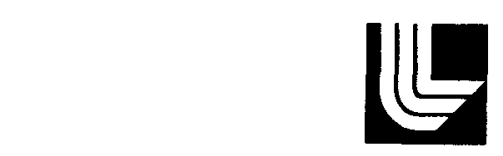

LAWRENCE LVERMORE LABORATORY

University of California/Livermore, Calitornia/94550

UCRL -51476

\title{
PREPARATION OF FISSION FOILS FOR FISSION IONIZATION CHAMBERS USING A PAINTING TECHNIQUE
}

\author{
James W. Behrens
}

MS. date: November 14, 1973

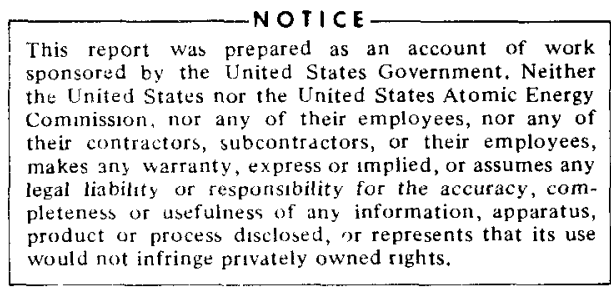




\title{
PREPARATION OF FISSION FOILS FOR FISSION IONIZATION CHAMBERS USING A PAINTING TECHNIQUE
}

\begin{abstract}
Fission foils for use in fission ionization chambers were produced by painting metal substrates with coats of fissionable isotopes. Areal densities as large as $2.0 \mathrm{mg} / \mathrm{cm}^{2}$ were obtained with excellent adhesion. This painting technique has been successful in depositing isotopes of uranium, plutonium, americium, and curium on metal substrates made of beryllium, aluminum, copper, and nickel.

We estimate the cost of this painting technique to be approximately one-tenth the cost of producing foils by evaporation, electrodeposition, or sputtering techniques. In addition, the painting technique is highly efficient, thereby minimizing waste of the available fissionable material. This fact is of great importance where only small amounts of rare high purity isotopes are available.
\end{abstract}

\section{Introduction}

For typical applications, fission ionization chambers usually contain fissionable material in the form of a thin oxide coating, between 0.1 and $2.0 \mathrm{mg} / \mathrm{cm}^{2}$ thick, on a metal foil. This coating may be painted, evaporated, electrodeposited, or sputtered. ${ }^{1}$ In 1944, Jorgenson described a spreading technique to produce thin uranium oxide films on platinum substrates. $^{2}$ This technique came to be called the Zapon spreading technique.

The Zapon spreading technique is basically as follows: An alcohol solution of the nitrate of the material to be deposited is mixed with a dilute solution of Zapon lacquer in acetone, alcohol, or Zapon thinner. The resulting solution is spread or painted on the substrate, allowed to dry, and then ignited to re- move organic substances and to convert the nitrate to an oxide. ${ }^{3}$

This report is a detailed description of our use of this technique to produce more than 300 fission foils for use in a variety of experimental neutron physics studies. Reference 4 is a preliminary report on the painting technique. The painting technique has been used to produce fission foils of such isotopes ${ }^{*}$ as ${ }^{233} \mathrm{U},{ }^{234} \mathrm{U},{ }^{235} \mathrm{U},{ }^{236} \mathrm{U},{ }^{238} \mathrm{U},{ }^{239} \mathrm{Pu}$, ${ }^{240}{ }_{\mathrm{Pu}},{ }^{241} \mathrm{Pu},{ }^{242} \mathrm{Pu},{ }^{24} 1_{\mathrm{Am}}$, and ${ }^{244} \mathrm{Cm}$ for use in making fission cross section measurements at a $100 \mathrm{MeV}$ electron linear accelerator.

\footnotetext{
${ }^{*}$ Most of these high purity isotopes were obtained from Oak Ridge National Laboratory and were separated using the Oak Ridge Calutrons.
} 


\section{Preparation of Foils}

Appendix A gives the details of making the painting solution. The maximum concentration of fissionable material in the painting solution will depend on the solubility of the nitrate of that element in the solvent (ethanol, methanol, acetone) and will be further limited to a certain maximum value within the solubility range to insure good adhesion of the isotope to the substrate. Appendix A lists recommended fissionable element concentrations for the painting solution.
Appendix B describes the recommended procedure for preparing fission foils. Beryllium, aluminum, copper, and nickel have been successfully used as substrates. Certain properties of these four elements are compared in Table 1 and Figure 1.

Beryllium substrates have the advantages of a high melting point and surface oxidation that starts at $600^{\circ} \mathrm{C}$. The high melting point permits the substrates to be baked at a very high temperature,

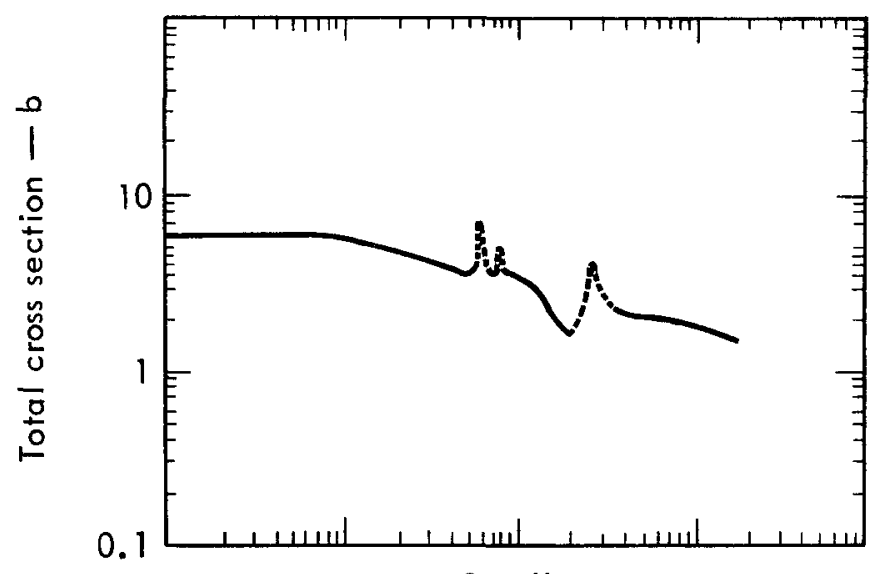

a. Beryllium

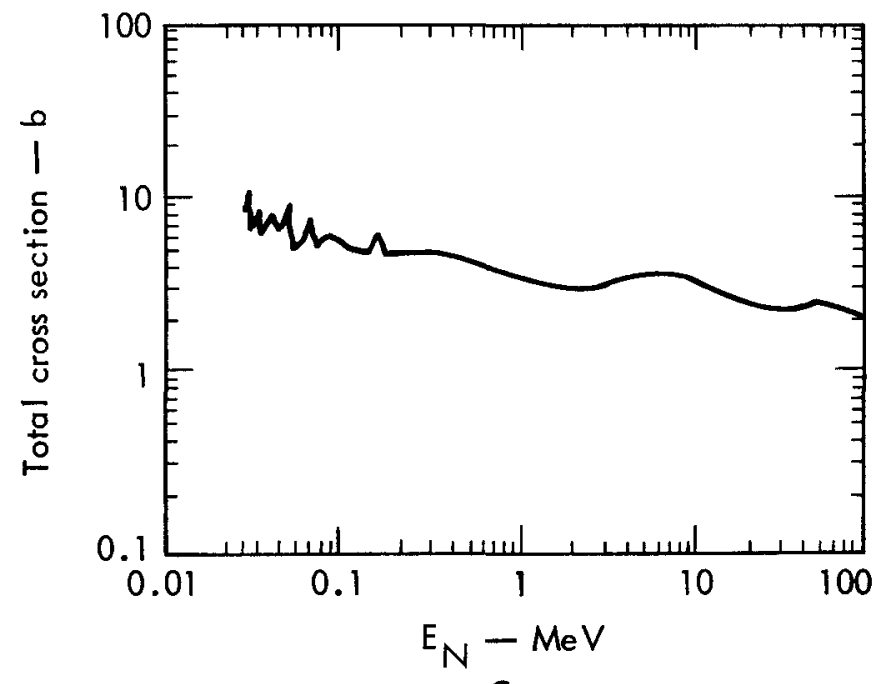

c. Copper

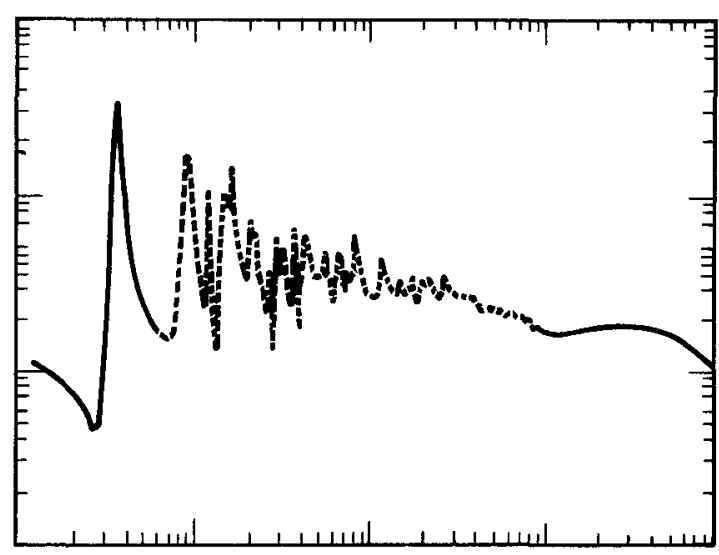

b. Aluminum

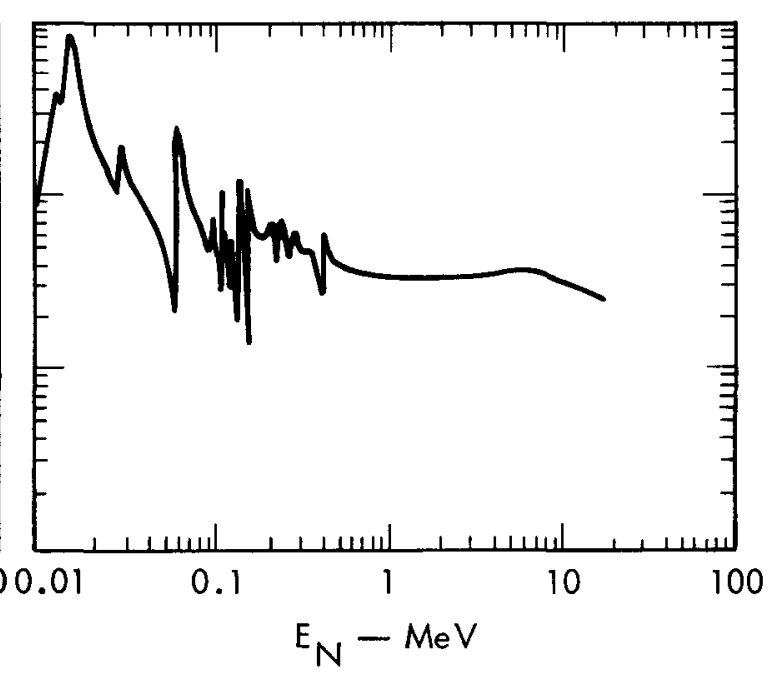

d. Nickel

Fig. 1. Total cross sections as a function of incident neutron energy for four elements. Curves taken from Ref. 5 . 
Table 1. Properties of the metal substrates.

\begin{tabular}{lrrrrrr}
\hline Substrate & Z & $\mathrm{A}$ & $\mathrm{g} / \mathrm{cc}$ & $10^{22}$ atoms/g & $10^{22}$ atoms/cc & $\begin{array}{c}\text { Melting } \\
\text { point } \\
\left({ }^{\circ} \mathrm{C}\right)\end{array}$ \\
\hline Beryllium & 4 & 9.01 & 1.85 & 6.66 & 12.3 & 1277 \\
Aluminum & 13 & 26.98 & 2.70 & 2.22 & 5.99 & 660 \\
Nickel & 28 & 58.71 & 8.9 & 1.02 & 9.08 & 1453 \\
Copper & 29 & 63.54 & 8.96 & 0.944 & 8.46 & 1083 \\
\hline
\end{tabular}

which better insures the burnoff of the lacquer and the conversion of the nitrate to oxide. The disadvantages are that beryllium is a hazardous material to handle and the metal is very brittle.

Aluminum substrates offer ease of handling, are able to take reasonable abuse, and have low surface oxide buildup. The disadvantage is the low melting point of aluminum, which limits the maximum temperature of the bakeout to $\sim 450^{\circ} \mathrm{C}$. Fission foils have been made using the painting technique on 4-in.-diam aluminum substrates of $0.05-\mathrm{mil}$ thickness, i.e. $343 \mu \mathrm{g} / \mathrm{cm}^{2}$, with areal densities of fissionable material up to $0.25 \mathrm{mg} / \mathrm{cm}^{2}$. With thin substrates we can usually detect both fission fragments, since the range of a fission fragment in aluminum is $\sim 0.5 \mathrm{mil}$, i.e. $3430 \mu \mathrm{g} / \mathrm{cm}^{2}$.

Copper and nickel substrates have the advantage of high melting points, but they also have rapid surface oxidation rates. To eliminate the surface oxidation of the metal, the bakeout should be done in an inert atmosphere such as argon. The lacquer will still burn off and the nitrate will still turn to oxide, but the substrate surface will not develop a thick oxide layer.

In the painting technique it is possible to apply multiple layers of fissionable material to the substrate. This involves a series of painting and baking repetitions and can produce areal densities of up to $2.0 \mathrm{mg} / \mathrm{cm}^{2}$ of fissionable material. Repeated painting of the substrate also improves the uniformity of the coating thickness. With care, the variation in uniformity of coating can be kept well under $10 \%$.

In certain neutron physics experiments it becomes important to minimize the perturbation of the incident neutron flux that is caused by the total foil thickness and the type of substrate used. In Table 1 the atoms/cc for the four substrate elements are given. In Fig. 1 the total cross sections as a function of incident neutron energy are compared for the four substrate elements. If the thickness of the substrate is $x \mathrm{~cm}$, then the transmission of neutrons of energy $E_{N}$ through that thickness is given by

$$
e^{-\left(\frac{\text { atoms }}{\mathrm{cc}}\right) \mathrm{x} \sigma_{\mathrm{T}}\left(\mathrm{E}_{\mathrm{N}}\right)}
$$

This factor should be taken into consideration when choosing a substrate and substrate thickness for a multiple parallel plate fission chamber. 


\section{Fission Foils in Fission Ionization Chambers}

An important use of fission foils is in fission ionization chambers. These fission chambers can be used to detect neutrons through the $(n, f)$ reaction or gammas through the $(\gamma, f)$ reaction of the fissionable material on the foils.

An example is the results from a planar ${ }^{239} \mathrm{Pu}$ parallel plate fission ionization chamber. The geometry and elec- tronics of this fission chamber are shown in Fig. 2. A PuBe sealed neutron source was used to induce fissions in the ${ }^{239} \mathrm{Pu}$. Figure 3 is a typical pulse height analysis spectrum. The clear separation of fission fragments from alpha particle pileup shown in this pulse height spectrum is clearly a desirable feature of the fission chamber system.

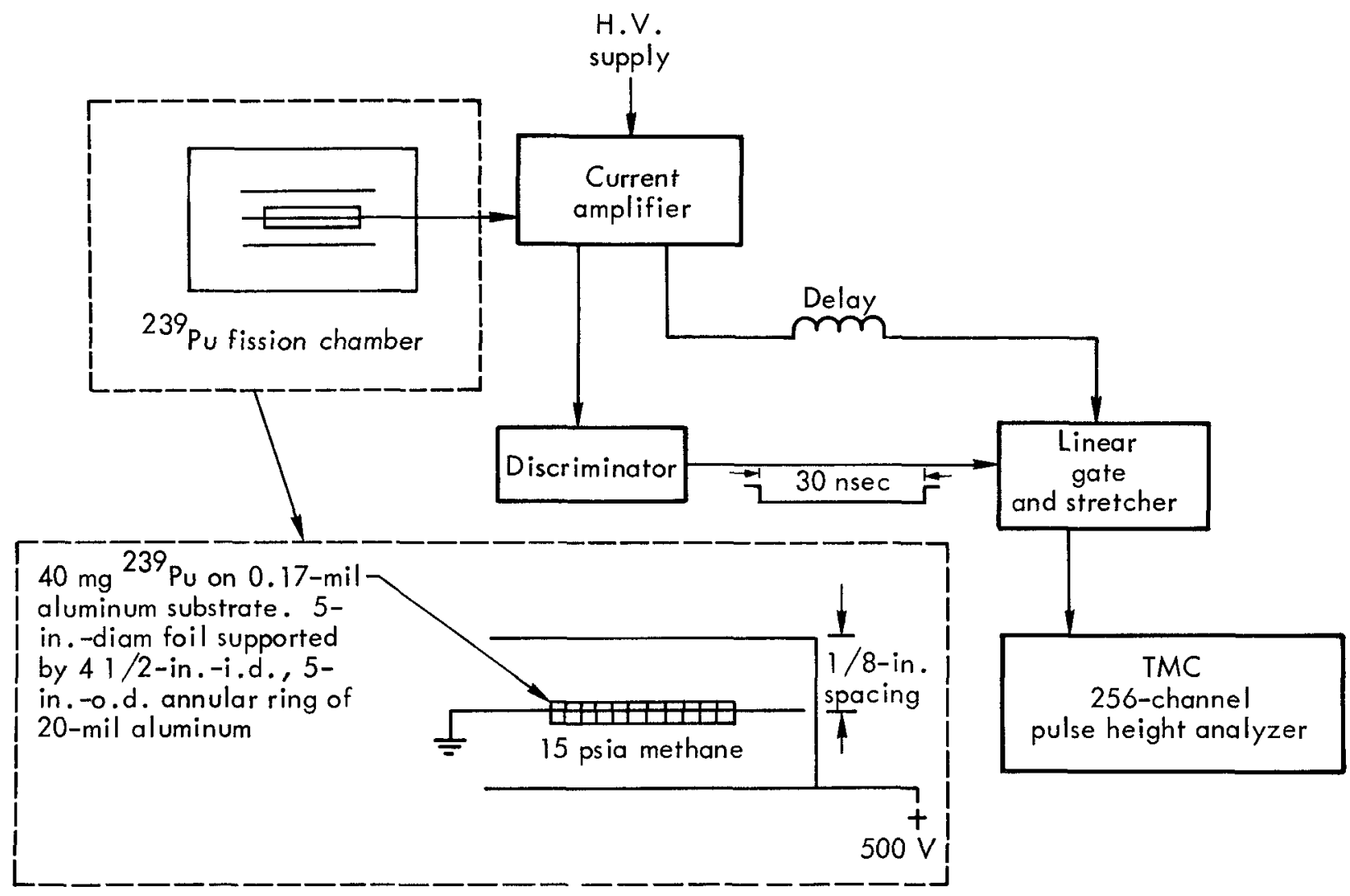

Fig. 2. Geometry and electronics setup for ${ }^{239} \mathrm{Pu}$ fission chamber pulse height analysis.

\section{Conclusions}

The painting technique is highly efficient when compared to other methods of producing fission foils. Upwards of $85 \%$ of the fissionable material will be deposited on the substrate if care is taken to minimize waste. This fact is of great 

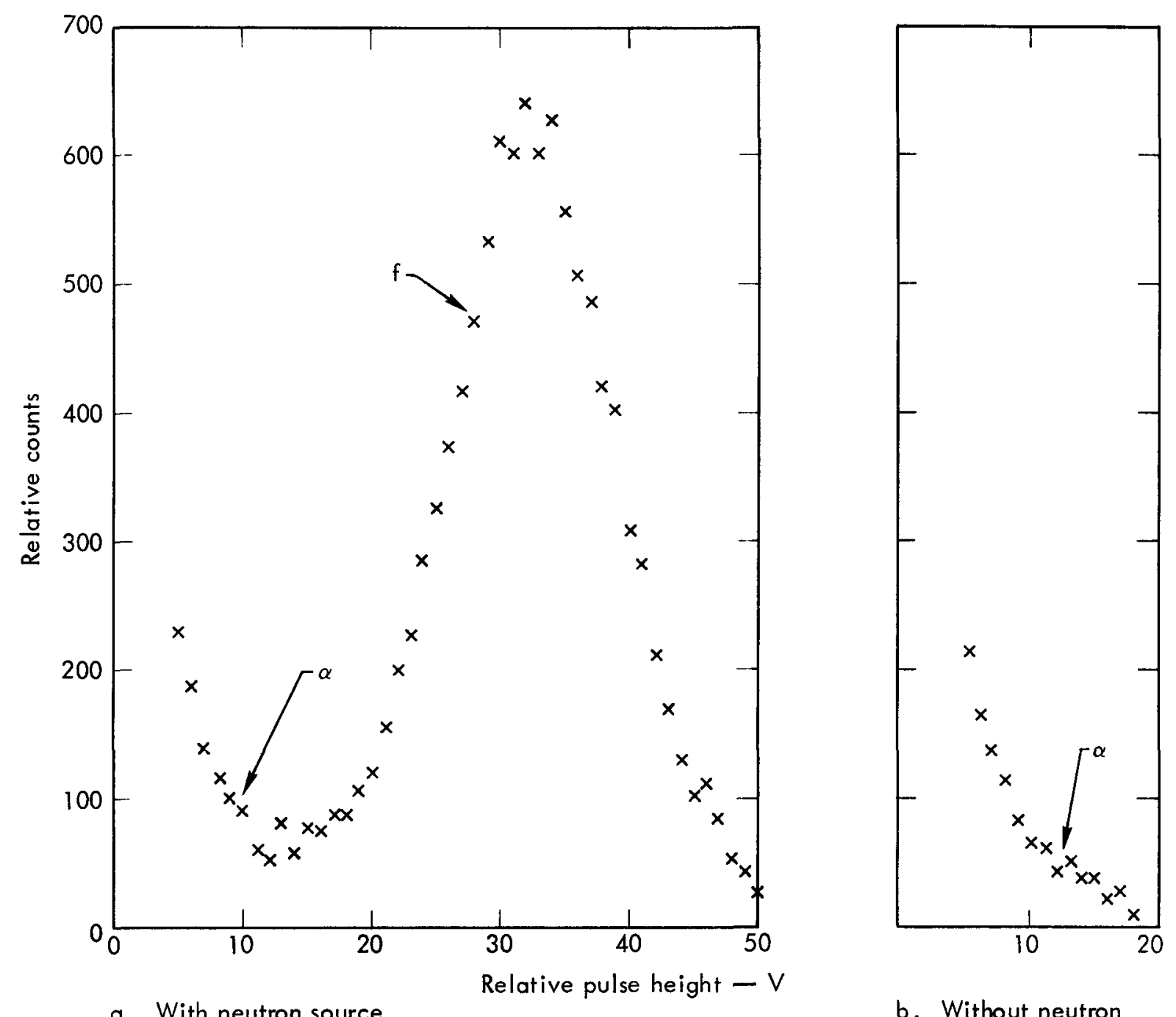

a. With neutron source b. Without neutron
source

Fig. 3. Typical pulse height analysis spectrum for ${ }^{239} \mathrm{Pu}$.

importance where only small amounts of rare high purity isotopes are available.

Minimal equipment is needed to make fission foils using the painting technique. As a result, the cost of this technique is approximately one-tenth the cost of producing foils by vacuum evaporation, electrodeposition, or sputtering techniques.

\section{Acknowledgments}

The author takes this opportunity to thank H. W. Kruger, A. H. Streicher, M. E. Harris, L. B. Noecker, R. E. Elson, J. C. Walden, J. W. Magana, J. L. Robbins, M. S. Coops, and W. N. Hayes for their help in this project. 


\section{References}

1. R. W. Lamphere, "Fission Detectors" in Fast Neutron Physics, J. B. Marion and J. L. Fowler, Eds. (Interscience Publishers, New York, 1960), p. 450.

2. T. Jorgenson, A Method for Making Thin Uranium Oxide Films on Platinum Foils, Los Alamos Scientific Laboratory, Los Alamos, New Mexico, Rept. LADC-209 (1944).

3. R. W. Dodson, "Preparation of Foils" in Miscellaneous Physical and Chemical Techniques of the Los Alamos Project, A. C. Graves and D. K. Froman, Eds. (National Nuclear Energy Ser. Div. V, vol. 3, 1952), p. 3.

4. J. W. Behrens, A Painting Process for Making Fission Foils, Lawrence Livermore Laboratory, Rept. UCID-15538 (1969).

5. D. J. Hughes and R. B. Schwartz, Neutron Cross Sections, Brookhaven National Laboratory, Upton, New York, Rept. BNL-325 (1958), pp. 89, 119, 165, 168. 


\section{Appendix A}

\section{Recommended Preparation of Painting Solution}

Solution 1: Prepare a lacquer/solvent solution by mixing $2.0 \mathrm{ml}$ of Glidden Foil Lacquer 131-C-707AX ${ }^{*}$ with $98.0 \mathrm{ml}$ of solvent. Suggested solvents are ethanol, methanol, or acetone. This produces a 2 vol\% lacquer stock solution. For a breakdown of the composition of formula 131-C-707AX, see

Table A-1.

Solution 2: Dissolve the nitrate of the fissionable material to be deposited at twice the final concentration desired in the same solvent used to make solution 1 . Refer to Table A-2 for recommended final concentrations.

Adding together equal volumes of solutions 1 and 2 will produce a 1 vol\% lacquer solution containing the desired final concentration of fissionable material.

Table A-1. Chemical breakdown of Glidden Foil Lacquer 131-C-707AX. ${ }^{a}$

\begin{tabular}{|c|c|}
\hline Material & $\mathrm{wt} \%$ \\
\hline $1 / 2 \sec ^{b}$ RS nitrocellulose ( $30 \%$ isopropanol) & 20.85 \\
\hline Flexol 13-13 $\left(\mathrm{C}_{6} \mathrm{H}_{4}\left(\mathrm{COO}_{13} \mathrm{CH}_{27}\right)\right.$ mixed isomers $)$ & 9.01 \\
\hline Ethylbenzene & 3.47 \\
\hline Super VM \& P naphtha (Standard Oil Chevron-265) & 12.85 \\
\hline Isopropyl alcohol $(99 \%)$ & 17.76 \\
\hline Methyl ethyl ketone & 7.40 \\
\hline Methanol & 14.40 \\
\hline Isopropyl acetate $(95 \%)$ & 7.94 \\
\hline Isobutyl acetate & 6.32 \\
\hline Total & 100.00 \\
\hline
\end{tabular}

\footnotetext{
anformation provided by R. E. Minucciani, Technical Director, Western Division, Glidden Durkee, Division of SCM Corporation.

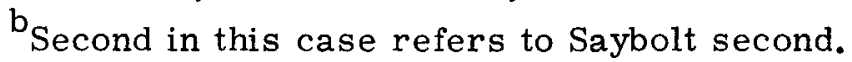

\footnotetext{
*Reference to a company or product name does not imply approval or recommendation of the product by the University of California or the U.S. Atomic Energy Commis sion to the exclusion of others that may be suitable.
} 
Table A-2. Recommended fissionable element concentrations for the painting solution.

\begin{tabular}{cc}
\hline Fissionable element & $\begin{array}{c}\text { Final concentration of } \\
\text { fissionable material } \\
\text { in paint solution } \\
(\mathrm{mg} / \mathrm{ml})\end{array}$ \\
\hline Uranium & $\leq 75$ \\
Plutonium & $\leq 25$ \\
Americium & $\leq 20$ \\
Curium & $\leq 8$ \\
\hline
\end{tabular}

${ }^{a}$ These concentrations are for the metal only. The nitrate of these metals is the actual compound that is dissolved in the solvent. 


\section{Appendix B}

\section{Recommended Procedure for Preparing Fission Foils}

Step 1. Cleaning the Substrates

Good adhesion of the fissionable material requires a clean substrate surface, free of grease, dirt, and fingerprints. Cleaning the substrate by using acids or other strong chemicals is not recommended; use ethanol, methanol, or acetone instead.

Step 2. Applying the Painting Solution

Apply the painting solution, prepared by following the steps in Appendix A, to the substrate using soft bristle paint brushes. Apply thin layers for the first two coatings. For thin substrates use a backing so the brush does not damage the substrate.

Step 3. The Baking Process

After the painting solution has dried on the substrate, place the foil in an oven and use the following heat treatment.

a. Heat slowly to a maximum temperature of $450^{\circ} \mathrm{C}$. This part should take from 15 to $30 \mathrm{~min}$. We performed an experiment to determine the amount of lacquer residue left in the coating after each heat treatment and determined that virtually all the lacquer burns off at $450^{\circ} \mathrm{C}$ maximum

b. Cool the foil to room temperature very slowly, taking 2 to $3 \mathrm{hr}$.

One of our ovens is the simple hot plate system shown in Fig. B-1. Hot plate systems like this are easy to use in glove boxes where high alpha activity isotopes are being deposited on the substrates. These ovens are easy to get inside the glove box and are very inexpensive.

Steps 2 and 3 are repeated until the desired coating thickness is reached.

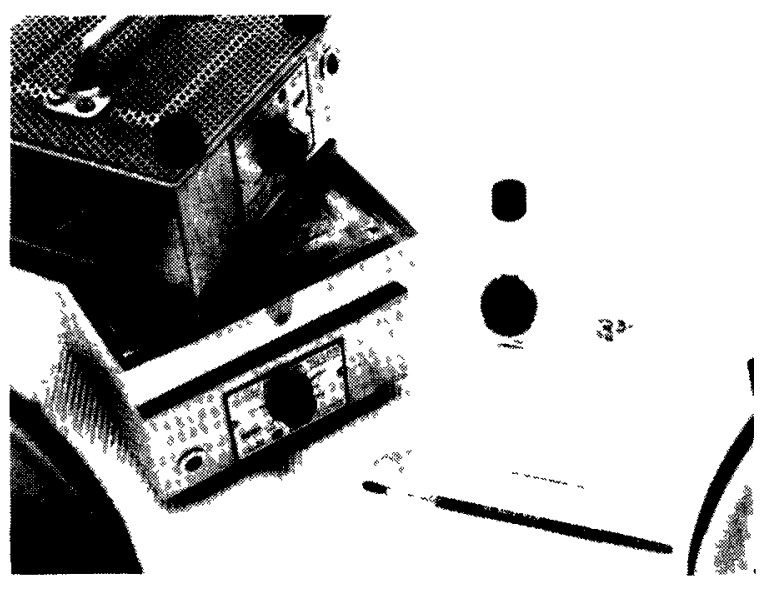

Fig. B-1. Hot plate system for use in glove box. 


\section{Distribution}

\section{LLL Internal D1stribution}

$\begin{array}{ll}\text { Roger E. Batzel } & \mathrm{L}-1 \\ \text { J. D. Anderson } & \mathrm{L}-312 \\ \text { J. C. Browne } & \mathrm{L}-221 \\ \text { M. S. Coops } & \mathrm{L}-515 \\ \text { J. B. CzIrr } & \mathrm{L}-221 \\ \text { R. E. Elson } & \mathrm{L}-402 \\ \text { M. E. Harris } & \mathrm{L}-128 \\ \text { W. N. Hayes } & \mathrm{L}-515 \\ \text { R. W. Hoff } & \mathrm{L}-232 \\ \text { H. W. Kruger } & \mathrm{L}-96 \\ \text { J. W. Magana } & \mathrm{L}-471 \\ \text { L. B. Noecker } & \mathrm{L}-471 \\ \text { J. L. Robbins } & \mathrm{L}-471 \\ \text { G. S. S1dhu } & \mathrm{L}-96 \\ \text { A. H. Stre1cher } & \mathrm{L}-122 \\ \text { R. L. Wagner } & \mathrm{L}-24 \\ \text { J. C. Walden } & \mathrm{L}-471 \\ \text { J. W. Behrens } & \mathrm{L}-24 \\ \text { TID F1le } & \mathrm{L}-9\end{array}$

External Distribution

C. D. Bowman

National Bureau of Standards

U.S. Department of Commerce

Washington, D.C. 20234

L, O, Love

E. H. Koblsk

J. H. Gillette

H. R. Gwinn

Oak Ridge National Laboratory

P. 0. Box X

Oak Ridge, Tennessee 37831

H. L. Ada1r

J. E. Ratledge

P. S. Baker

Oak Ridge National Laboratory

P. 0. Box X

Oak Ridge, Tennessee 37831

M. S. Moore

J. G. Povelites

Los Alamos Scientific Laboratory

P. 0. Box 1663

Los Alamos, New Mexico 87544
R. G. Damm Argonne National Laboratory Argonne, Illinots 60439

R. E. Vallee Monsanto Research Comp. P. 0. Box 32 Miamisburg, Oh1o 45342

W. V. Conner Dow Chemical Company Rocky Flats Division

P. O. Box 888

Golden, Colorado 80402

J. A. Mogford

Sandia Laboratories

P. O. Box 969

Livermore, Californta 94550

E. A. Walker

U.S. Atomic Energy Commission Dayton Area office

P. 0. Box 66

Miamisburg, Ohto 45342

J. W. Neh1s

U.S. Atomic Energy Commisston Oak Ridge Operations Office Oak RIdge, Tennessee 37831

A. R. Van Dyken

G. L. Rogosa

U.S. Atomic Energy Commission Headquarters

Washington, D.C.

I. A. Hobbs

E. I. du Pont de Nemours

Savannah River Plant

Atken, South Carolina 29801

R. E. Minucciant

Glidden-Durkee

Division of SCM Corp.

P. 0. Box 7710

1000 Sixteenth Street

San Franctsco, Californta 94119

TID-4500 Distribution, Category UC-25 Materials 